\title{
Thymus in Myasthenia Gravis \\ Isolation of T-Lymphocyte Lines Specific for the Nicotinic Acetylcholine Receptor from Thymuses of Myasthenic Patients
}

\author{
A. Melms, ${ }^{*}$ B. C. G. Schalke, ${ }^{\ddagger}$ Th. Kirchner, ${ }^{5}$ H. K. Müller-Hermelink, E. Albert," and H. Wekerle* \\ *Max-Planck-Society, Clinical Research Unit for Multiple Sclerosis, Würzburg, D-8700 Würzburg, Federal Republic of Germany; \\ ${ }^{\ddagger}$ Departments of Neurology and ${ }^{\S}$ Pathology University of Würzburg, D-8700 Würzburg, Federal Republic of Germany; \\ "Department of Pediatrics, University of Munich, Münich, Federal Republic of Germany
}

\begin{abstract}
The thymus is believed to play a central role in the pathogenesis of Myasthenia gravis (MG). According to a previous hypothesis, MG is initiated within the thymus by immunogenic presentation of locally produced nicotinic acetylcholine receptor $(\mathrm{AChR})$ to potentially autoimmune $T$ cells. Data of 10 consecutive MG patients demonstrate two critical features of MG thymuses that support the concept of intrathymic activation of autoreactive, AChR-specific lymphocytes. Morphologically, the thymuses showed lympho-follicular hyperplasia in nine cases and benign thymoma in one case. The paramount feature revealed by immunohistological double marker analyses was the intimate association of myoid cells (antigen producing) with interdigitating reticulum cells (potentially antigen presenting cells), both of which were surrounded by $\mathrm{T3}^{+}$lymphocytes in thymus medulla. All 10 thymuses contained $\mathbf{T}$ lymphocytes reactive with $\mathrm{AChR}$. This was in contrast to the peripheral immune compartment (blood) where in only 3 of 10 patients, significant $T$ cell responses to $A C h R$ were observed. AChR-specific $T$ cell lines could be established from 8 of 10 thymuses, all members of the helper/inducer subset as indicated by the expression of markers T3 and T4.
\end{abstract}

\section{Introduction}

The thymus is profoundly involved in the pathogenesis of myasthenia gravis (MG). ${ }^{1}$ It is generally known that most, if not all myasthenia patients have pathological changes of their thymic tissue. Specifically, $>70 \%$ of all myasthenic thymuses show lymphofollicular hyperplasia, and at least $10 \%$ of myasthenic patients have thymic epithelial neoplasia (1).

A causal connection between thymic changes and the development of clinical MG has been suggested by the beneficial therapeutic effects of thymus extirpation. In fact, at least in MG with short duration of symptoms, associated with thymus hyperplasia, thymectomy appears to be one of the most re-

Address reprint requests to Dr. Wekerle, Max Planck Society, Clinical Research Unit for Multiple Sclerosis, P.O. Box 61 20, D-8700 Wurzburg, FRG.

Received for publication 27 July 1987 and in revised form 21 September 1987.

1. Abbreviations used in this paper: $\mathrm{AChR}$, acetylcholine receptor; MG, myasthenia gravis.

J. Clin. Invest.

(C) The American Society for Clinical Investigation, Inc.

0021-9738/88/03/0902/07 \$2.00

Volume 81, March 1988, 902-908 warding therapeutic measures (2-5). Finally, at least an indirect role of the thymus was indicated by the demonstration of putatively thymus-dependent cellular responses against the nicotinic acetylcholine receptor (AChR) in MG patients (6-8).

This clinical experience together with the observation of myogenic inducibility of thymic stem cells in culture (9) led us to postulate that in MG the thymus is the primary site of a pathogenic autoimmune response against the postsynaptic $\operatorname{AChR}(10,11)$. We proposed a four-step sequence of intrathymic pathogenesis: (a) myogenic induction of primitive thymic stem cells leading to synthesis and expression of $\mathrm{AChR}$ on thymic myoid cells; $(b)$ release of AChR from myoid cells, perhaps due to cell death, and uptake of myoid AChR by thymic antigen presenting cells (e.g., interdigitating cells, IDC) and immunogenic presentation; $(c)$ recognition of immunogenically presented AChR by specific autoreactive T lymphocytes, differentiating within the thymus; $(d)$ emigration of the activated AChR specific $T$ lymphocytes to the peripheral immune system, interaction with AChR specific B cells resulting in the production of pathogenic anti-AChR autoantibodies.

This report supports a central element of the concept of intrathymic generation of MG. We demonstrate that thymus tissues from myasthenic patients indeed regularly contain $T$ lymphocytes which can recognize and react against $A C h R$. There is evidence that AChR specific $T$ cells are more frequent within the thymus than in peripheral compartments of the immune system, e.g., peripheral blood. We furthermore show that these $\mathrm{T}$ cells can be isolated and propagated as AChR specific $T$ cell lines and that all the $T$ cell lines recovered express membrane markers of the CD4 $\mathrm{T}$ cell subset.

\section{Methods}

Patients. All patients were seen in the Department of Neurology (Director, Prof. Dr. H. G. Mertens) of the University of Würzburg, and are participants in a double-blind controlled trial comparing the benefits of longterm immunosuppression of cyclosporin A vs. azathioprine (12).

Diagnosis of MG was based on clinical examination, amplitude decrement during repetitive EMG stimulation, positive edrophonium and/or curare test. Clinical grading was done according to Osserman (13). In 9 of 10 patients anti-AChR antibodies were determined (Dr. I. Kalies, Erlangen). Transsternal thymectomy was performed at the Department of Thoracic Surgery of the University of Würzburg. All patients gave written consent for their specimens to be used for research.

Antigens. A preservative free preparation of tetanus toxoid (TT) was used (Behring-Werke AG, Marburg, FRG; lot no. 831832, 2860 $\mathrm{IU} / \mathrm{ml}$ ) at a final concentration $0.1-1.0 \mathrm{IU} / \mathrm{ml}$.

AChR of Torpedo californica electric organ (Pacific Biomarine Lab., Venice, CA) was prepared as described (14). Some preparations were done according to Rüchel et al. (15). Electroplax tissue was 
minced in the presence of enzyme inhibitors PMSF (Sigma Chemical Co., St. Louis, MO, $10^{-4} \mathrm{M}$ ) Iodoacetamide (Sigma Chemical Co., St. Louis, MO, $\left.5 \times 10^{3} \mathrm{M}\right)$, EDTA $\left(10^{-3} \mathrm{M}\right.$; Sigma Chemical Co. $)$ in cold $50 \mathrm{mM}$ phosphate buffer $\mathrm{pH}$ 7.4. After centrifugation $(30,000 \mathrm{~g}, 30$ min) the pellet was resuspended in $5 \mathrm{mM}$ phosphate buffer $\mathrm{pH} 7.4$ containing 2\% Triton X-100 (Merck AG, Darmstadt, FRG) and extracted on a stirrer for $2 \mathrm{~h}$. After a second centrifugation the supernatant that contained solubilized $\mathrm{AChR}$ was stored at $-80^{\circ} \mathrm{C}$ or applied to a $\alpha$-cobratoxin linked $\mathrm{CNBr}$ Sepharose column. After washing with buffer, AChR was competitively eluted with $0.2 \mathrm{M}$ carbamylcholine (Sigma Chemical Co.) or $0.1 \mathrm{M}$ hexamethoniumbromide (Fluka, Buchs, Switzerland). AChR was concentrated on a DEAE-A 25 column (Pharmacia Fine Chemicals, Freiburg, FRG) and eluted in a small volume by buffer containing $0.5 \mathrm{M} \mathrm{NaCl}$. Before use in tissue culture, the detergent Triton X-100 had to be reduced by dialysis for 7 $\mathrm{d}$ in $5 \mathrm{mM}$ phosphate buffer, $\mathrm{pH}$ 7.4. AChR had a specific activity of 4.8-8.0 $\mathrm{nM} \alpha$-bungarotoxin binding sites/mg protein as determined by a ${ }^{125} \mathrm{I}-\alpha$-bungarotoxin binding assay (16). Concentration in tissue culture was $1 \mu \mathrm{g} / \mathrm{ml}\left(\sim 4 \times 10^{-9} \mathrm{M} \mathrm{AChR}\right)$.

HLA-typing. Typing of HLA-A, $-\mathrm{B},-\mathrm{C}$ as well as HLA-DR, -DQ antigen was done by the National Reference Laboratory (Prof. Dr. E. Albert, Munich, FRG) using standard typing material as defined by the 6th Workshop on Histocompatibility Testing 1984 (17).

Isolation of PBMC. PBMC from EDTA blood were isolated by density centrifugation on Lymphoprep gradients (Nygaard, Oslo, Norway) for $30 \mathrm{~min}$ at $800 \mathrm{~g}$. After being washed in $\mathrm{Ca}^{2+}-\mathrm{Mg}^{2+}$ free PBS, $2 \times 10^{5}$ cells/well were cultured in 96 well microtiter plates (Nunc, Roskilde, Denmark) in RPMI 1640 medium (Gibco Laboratories, Grand Island, NY) plus $2 \%$ pooled human serum, $2 \mathrm{mM}$ glutamine (Gibco), $100 \mathrm{U} / \mathrm{ml}$ penicillin and $100 \mu \mathrm{g} / \mathrm{ml}$ streptomycin (Biochrom, Berlin, FRG) i.e., complete medium (CM) in the presence or absence of antigen or mitogen (TT $1.0 \mathrm{IU} / \mathrm{ml}$, AChR $1 \mu \mathrm{g} / \mathrm{ml}$, PHA-P $5 \mu \mathrm{g} / \mathrm{ml}$ ). Cultures were incubated in $95 \%$ air, $5 \% \mathrm{CO}_{2}$ for $5 \mathrm{~d}$. We pulsed the cultures with $0.2 \mu \mathrm{Ci}\left(\left[{ }^{3} \mathrm{H}\right]\right.$ thymidine $\left[{ }^{3} \mathrm{H}\right] \mathrm{TdR}$, Amersham-Buchler, Braunschweig; specific activity $5 \mathrm{mCi} / \mathrm{mM}$ ) for $16 \mathrm{~h}$. before harvesting onto glass fiber filters by a Skatron Cell Harvester. Incorporated $\left[{ }^{3} \mathrm{H}\right]$ thymidine was measured by liquid scintillation counting in a beta-counter (Kontron, Basel, Switzerland).

Preparation of thymocyte cell suspension. Thymus specimens were obtained at surgery and kept in cold Hepes buffered DME (Dulbecco's modified Eagle's medium; Gibco). Connective tissue of the fibrous capsule, septa and blood vessels were carefully removed. The trimmed thymus lobules were rinsed with DME to further minimize red blood cell contamination. Coarse mincing by scissors was followed by homogenization in a loosely fitting glass tissue homogenizer (Bellco, Vineland, NJ). The cell suspension was filtered through nylon wool to remove large particles. Aliquots of this single cell suspension were used for culture experiments, immunostaining, or were stored in liquid nitrogen. For tissue culture and staining experiments thymocytes could be fractionated on a discontinuous BSA gradient (Sigma Chemical Co.; density $1.081 \mathrm{~g} / \mathrm{ml}$ ) into low density (LD) and high density (HD) thymocytes. Most culture experiments were done with the LDfraction that appeared to be enriched for $\mathrm{DR}^{+}$and surface $\mathrm{Ig}^{+}$cells as compared to the original cell suspension (Table II).

Thymocyte cultures. 3-4 $\times 10^{5}$ LD-thymocytes were cultured in triplicates in CM (conditions see culture of PBMC) for 7-10 d without adding exogenous IL-2. Activated cells were separated by density gradient centrifugation and expanded in IL-2 containing growth medium (5-10 U/ml lymphocult HP; Biotest Diagnostics, Frankfurt, FRG). At 10-14-d intervals cells were restimulated with antigen presented by thawed autologous LD-thymocytes as described below.

Microproliferation assay. $2 \times 10^{4}$ antigen activated $\mathrm{T}$ lymphoblasts (from PBMC or thymus culture) were cultured in doublicates or triplicates with or without $2 \times 10^{5}$ irradiated ( $40 \mathrm{~Gy}$ ) autologous PBMC or in the case of thymus cultures $3-4 \times 10^{5}$ irradiated ( $40 \mathrm{~Gy}$ ) autologous LD-thymocytes in $0.2 \mathrm{ml} \mathrm{CM}$ in the presence or absence of antigen or mitogen (see PBMC cultures). After $72 \mathrm{~h}$ cells were pulsed with $\left[{ }^{3} \mathrm{H}\right]-$ $\mathrm{TdR}$ and harvested $16 \mathrm{~h}$ later.

Analysis of lymphocyte populations with a FACS. Cytofluographic analysis of cell populations was performed by means of indirect immunofluorescence with fluoresceine conjugated $F(a b)_{2}$ fragment of goat anti-mouse IgG (Medac, Hamburg, FRG; dilution 1:100) on an Ortho 30/50 system (Ortho, Neckargemünd, FRG) using a linear scale.

Reagents Leu 3a, Leu 2a, anti-HLA-DR, anti-IL-2-receptor were purchased from Becton-Dickinson (Heidelberg, FRG), OKT 3, OKT 4, OKT 6, and OKT 8 were from Ortho, anti-human Ig-FITC was from Miles (Münich). All reagents were diluted 1:200. Background fluorescence activity (usually $<2 \%$ ) was determined by incubation with the second antibody alone. This value was substracted from the individual results.

Immunohistochemistry. For a double marker analysis, combined staining with immunoperoxidase and alkaline phosphatase was applied to $5-\mu \mathrm{m}$ thick cryostat sections of fresh thymus tissue. The sections were fixed with acetone for $10 \mathrm{~min}$ at room temperature and air dried.

The monoclonal antibodies used were: $(a)$ OKT 3, diluted 1:100; (b) KiM 1 (18), diluted 1:4000; (c) KiM 4 (19), diluted 1:5,000; (d) anti-desmin (Laboserv, Giessen, FRG), diluted 1:5. All antibodies were diluted with 0.1 M PBS, pH 7.4.

Demonstration of the first antigen was performed by the indirect immunoperoxidase technique using a three stage procedure, as described by Stein et al. (20). After this reaction the immune staining of

Table I. Clinical Data

\begin{tabular}{|c|c|c|c|c|c|c|c|c|c|c|c|c|c|c|c|c|}
\hline Patient & No. & Sex & Age & $\begin{array}{l}\text { Duration of } \\
\text { symptoms }\end{array}$ & $\begin{array}{l}\text { Immuno- } \\
\text { suppression }\end{array}$ & Thymus pathology & $\begin{array}{l}\text { Osserman } \\
\text { type }\end{array}$ & $\begin{array}{l}\text { Anti- } \\
\text { AChR }\end{array}$ & & & & & A-typing & data & & \\
\hline ER & 1 & $\mathbf{F}$ & 32 & $13 \mathrm{mo}$ & 0 & $\begin{array}{l}\text { Lympho-follicular } \\
\text { Hyperplasia }\end{array}$ & IIB & * & Al & & B8 & Bw57 & Cw6,7 & DR3 & DR7 & DQw2,2 \\
\hline $\mathbf{K P}$ & 2 & $\mathbf{F}$ & 23 & $9 \mathrm{mo}$ & 0 & Hyperplasia & II $\mathbf{B}$ & + & Al & A24 & B8 & B44 & & DR2 & DR3 & DQw1,2 \\
\hline SM & 3 & $\mathbf{F}$ & 19 & $22 \mathrm{mo}$ & 0 & Hyperplasia & II B & + & A2 & A30 & B8 & B35 & Cw4 & DR3 & DRw14 & DQw1,2 \\
\hline HR & 4 & $\mathbf{F}$ & 25 & $6 \mathrm{mo}$ & 0 & Hyperplasia & II B & + & Al & A2 & B7 & B8 & Cw7 & DR2 & DR3 & DQw1,2 \\
\hline JS & 5 & $\mathbf{F}$ & 17 & $13 \mathrm{mo}$ & 0 & Hyperplasia & II B & + & A11 & A28 & B7 & B51 & $\mathrm{Cw} 7$ & DRw6 & DRw10 & DQw1,1 \\
\hline JB & 6 & $\mathbf{F}$ & 16 & $6 \mathrm{mo}$ & 0 & Hyperplasia & II A & + & $\mathrm{A} 2$ & Al1 & B13 & Bw4 & Cw 1,3 & DR2 & DRw9 & DQw1,- \\
\hline DE & 7 & $\mathbf{F}$ & 60 & $20 \mathrm{yr}$ & yes & Benign thymoma & II A & ND & Al & A2 & B7 & B51 & Cw7 & DR 1 & DR2 & DQw1,1 \\
\hline $\mathrm{NC}$ & 8 & $\mathbf{F}$ & 22 & $12 \mathrm{mo}$ & 0 & $\begin{array}{l}\text { Lympho-follicular } \\
\text { Hyperplasia }\end{array}$ & II B & + & Al & A28 & B8 & B51 & Cw4,7 & DR 1 & DR3 & DQw1,2 \\
\hline PC & 9 & $\mathbf{F}$ & 23 & $4 \mathrm{mo}$ & 0 & Hyperplasia & II $\mathbf{B}$ & + & Al & A32 & B8 & & $\mathrm{Cw} 7$ & DR3 & DRw6 & DQw1,2 \\
\hline $\mathbf{R G}$ & 10 & $\mathbf{F}$ & 20 & $5 \mathrm{mo}$ & 0 & Hyperplasia & II B & + & Al & A24 & B8 & B35 & $\mathrm{Cw} 7$ & DR3 & DRw6 & DQw1,2 \\
\hline
\end{tabular}

* Less than $0.4 \mathrm{nM} / 1$-bungarotoxin binding sites. 
a
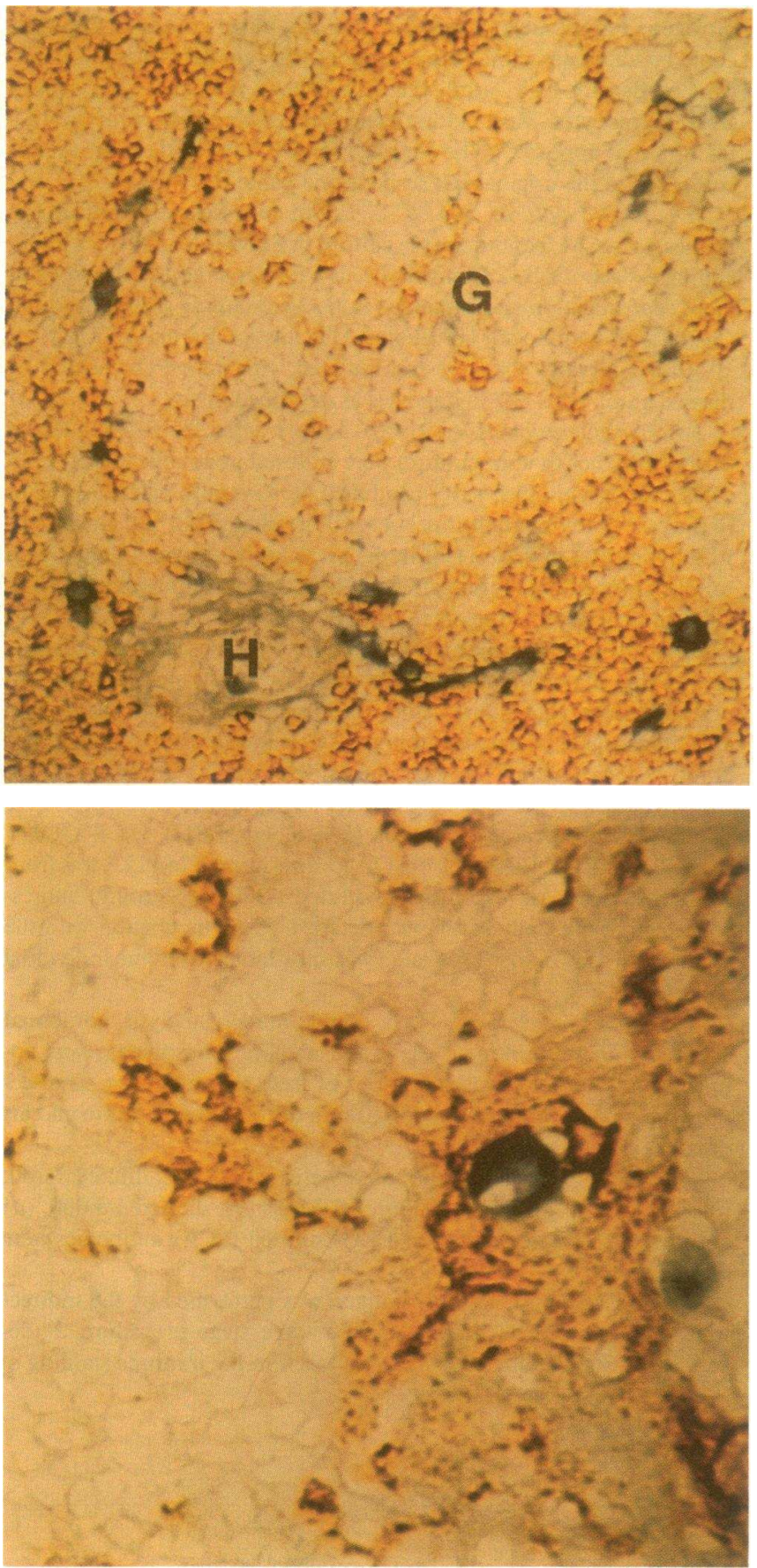

c

the second antigen was achieved by the alkaline phosphatase method following the description of Feller et al. (21).

\section{Results}

Myasthenia patients. We analyzed peripheral blood lymphocytes and thymus cells from 10 MG patients who consecutively underwent transsternal thymectomy for therapeutic reasons (Table I). All were female. With one exception, their symptoms were present for $<2$ yr with clinical severity corre- b

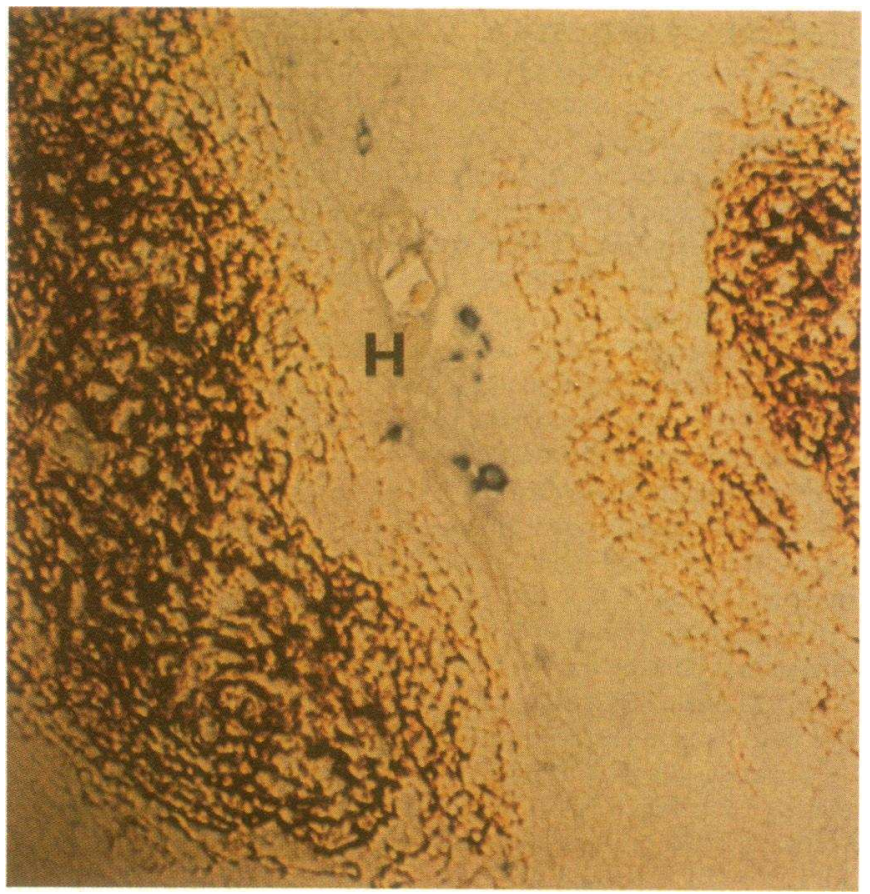

Figure 1. Double immunostaining of MG thymus. (a) Localization of desmin-positive myoid cells (blue) in the medullary area of OKT 3-positive $T$ cells (brown) around a germinal center $(G)$. The medulla contains a Hassall's corpuscle $(H)(\times 190)$. (b) Demonstrating desmin-positive myoid cells (blue) near a Hassall' corpuscle $(H)$ and outside the network of $\mathrm{KiM}$ four-positive dendritic reticulum cells (brown) of germinal centers $(\times 150)$. (c) Close contact of a desminpositive myoid cell (blue) and $\mathrm{KiM}$ 1-positive interdigitating cells (brown) $(\times 600)$.

sponding to Osserman classification type II A or II B. No previous immunosuppression had been given. The thymus of these patients showed typical lymphofollicular hyperplasia.

In contrast to all other patients, patient $D$. E. was found to have a benign thymoma. This patient had been treated transiently with azathioprine. Disease duration was $20 \mathrm{yr}$.

The HLA phenotype was determined serologically in 10 patients. 6 of 10 patients had associated B8 and DR3 haplotypes, a combination that in particular in young females with 
thymic lymphofollicular hyperplasia is thought to be linked to a mildly enhanced disease susceptibility (22). None of our patients was demonstrated to be homozygous in the DR region.

Association of myoid cells, dendritic cells and $\mathrm{T3}^{+}$lymphocytes in thymus medulla. All thymuses with lymphofollicular hyperplasia showed marked expansion of the perivascular space, and marked "peripheralization" of the medullary areas. Germinal centers were frequent and surrounded by $\mathrm{T}$ lymphocyte areas of peripheral phenotype. A hallmark of all MG thymuses was the intimate association of myoid cells with IDCs, and their localization in areas occupied by "mature" $\mathrm{T}^{+}$, thymic lymphocytes. In contrast, myoid cells were never seen in germinal centers. (Fig. 1). Thymic tissue from non-MG patients obtained by heart surgery (seven cases) or autopsy (three cases) also contained myoid cells, but they were only very rarely associated with IDCs (23).

Primary antigen reactivity of peripheral blood and thymic lymphocytes. Lymphocyte suspensions (PBL) were prepared from peripheral blood samples and, in parallel, from specimens of freshly excised thymus tissue (Fig. 2). Specific reactivity against AChR and against TT was assessed in vitro in primary microcultures. With the exception of three patients (J.S., J.B., D.E.) all peripheral blood lymphocytes cultures responded by proliferation to TT. In contrast, reactivity of the same PBL cultures to AChR was much lower in each case.
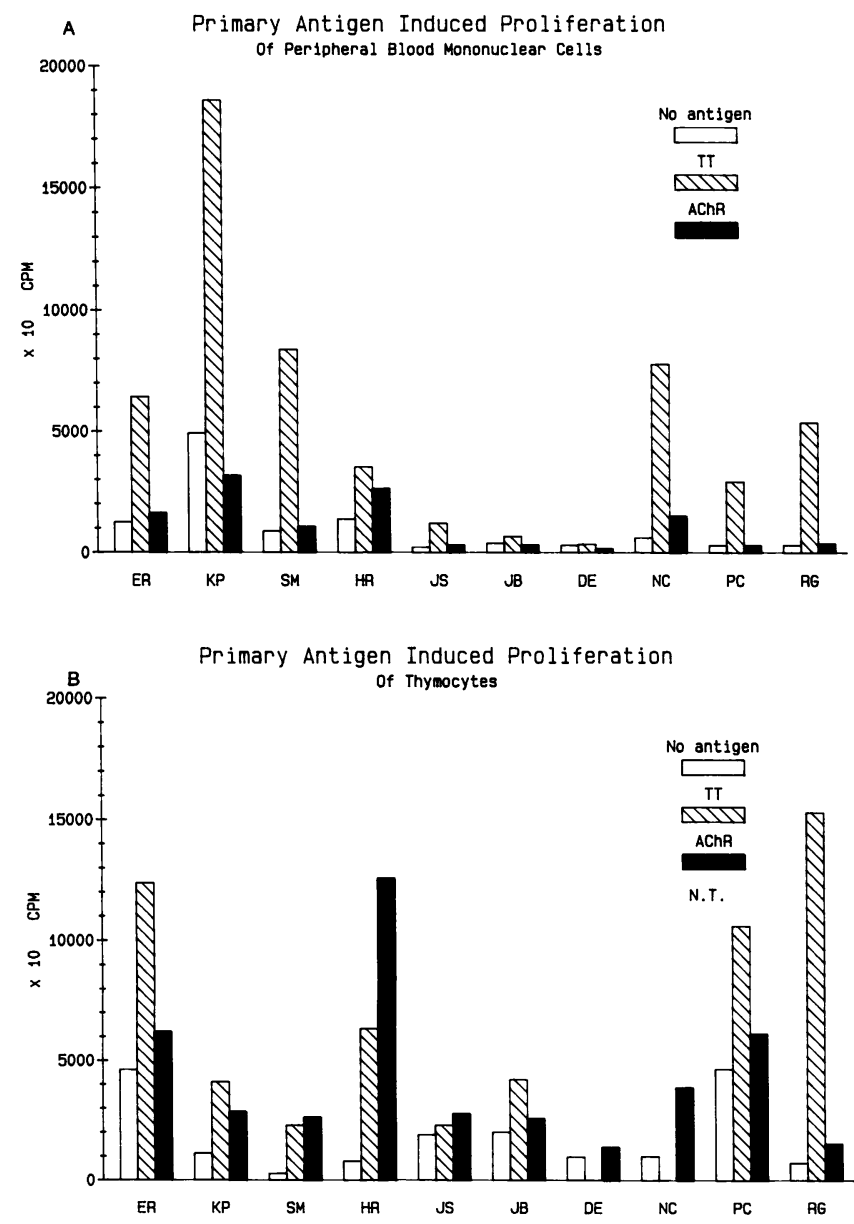

Figure 2. Primary antigen induced proliferation of $2 \times 10^{5}$ PBMC (a) and 3-4 $\times 10^{5}$ LD-thymocytes $(b) ;\left[{ }^{3} \mathrm{H}\right]$ thymidine incorporation, mean of triplicates $\pm \mathrm{SD}$. DE, NC; not tested.
Significant reactions were seen in three of nine patient cultures only.

The pattern of antigen reactivity in primary thymus cell cultures did not principally differ from the one in PBL cultures. Two features appear, however, worth mentioning. First of all, like PBL cultures, most primary thymus cultures showed reactivity against TT (7/8). There was, however, a relative increase of the primary $\mathrm{AChR}$ reactivity as compared to the PBL cultures. 9 of 10 thymuses contained cells that reacted primarily against $\mathrm{AChR}$, and, remarkably, the amplitude of AChR reactions in some cases approached or even surpassed the one against TT, which was in striking contrast to the very low AChR reactivity in PBL cultures. Second, in thymus cultures more often than in PBL cultures, $T$ cell proliferation was observed in the absence of any added exogenous (auto-)antigen.

$T$ lymphocyte lines specific for $A C h R$ or $T T$ from myasthenic thymus and peripheral blood. After confrontation with either AChR or TT in primary cultures activated T lymphoblasts were isolated by density gradient centrifugation, cultured in the presence of IL-2 containing media, and were then again restimulated with antigen presented by autologous antigen-presenting cells. Cyclic alternation of antigen stimulation and IL-2-dependent $T$ cell propagation is the principle for establishing antigen monospecific $\mathrm{T}$ lymphocyte lines. We selected AChR and TT specific T lines both from thymic and from PBL primary cultures. In contrast to the low success rate in obtaining $A C h R$ specific $T$ lines from myasthenic peripheral blood (3/10 attempts), it was remarkable that $\mathrm{T}$ lines were selected from 8 of 10 myasthenic thymuses (Fig. 3). Furthermore, AChR specific $\mathrm{T}$ lines could be derived not only from freshly processed thymus samples but from frozen samples as well. All these cell populations were strongly reactive against the AChR, but had lost their reactivity to TT. Reactivity against accessory cells alone, independent of the presentation of AChR (i.e., self-mixed lymphocyte reaction) varied between individual $\mathrm{T}$ lines. TT specific $\mathrm{T}$ cell lines were successfully selected from 7 of 8 thymus specimens (data not shown). They were highly reactive against the selecting antigen, TT, but ignored AChR. SMLC activity was seen in three of these cultures. Completely similar $\mathrm{T}$ lines were derived from peripheral blood at high success rate ( $4 / 6$ attempts). All $\mathrm{T}$ lines investigated, irrespective of their antigen specificity or organ origin, expressed the mature CD 4 membrane phenotype. Staining with a standard set of monoclonal antibodies and appropriate fluorescent reagents established expression of $T 3$ and $T 4$ determinants on all the lines but not $\mathrm{T} 8, \mathrm{~T} 6$ nor membrane immunoglobulins (Table II).

\section{Discussion}

This report demonstrates $A C h R$ reactive $T$ lymphocytes in thymic tissues obtained from a series of 10 thymectomies of MG patients presenting successively at our clinic. Primary $T$ cell stimulation was corroborated by the establishment of AChR specific $T$ lines from $8 / 10$ cases. We thus show that myasthenic thymuses regularly harbor significant numbers of autoreactive T lymphocytes specific for AChR.

Which stimulus could activate and expand the intrathymic AChR specific T cell clones? The most plausible possibility is AChR produced locally and presented in an immunogenic way. AChR is synthesized in rich amounts by intrathymic 


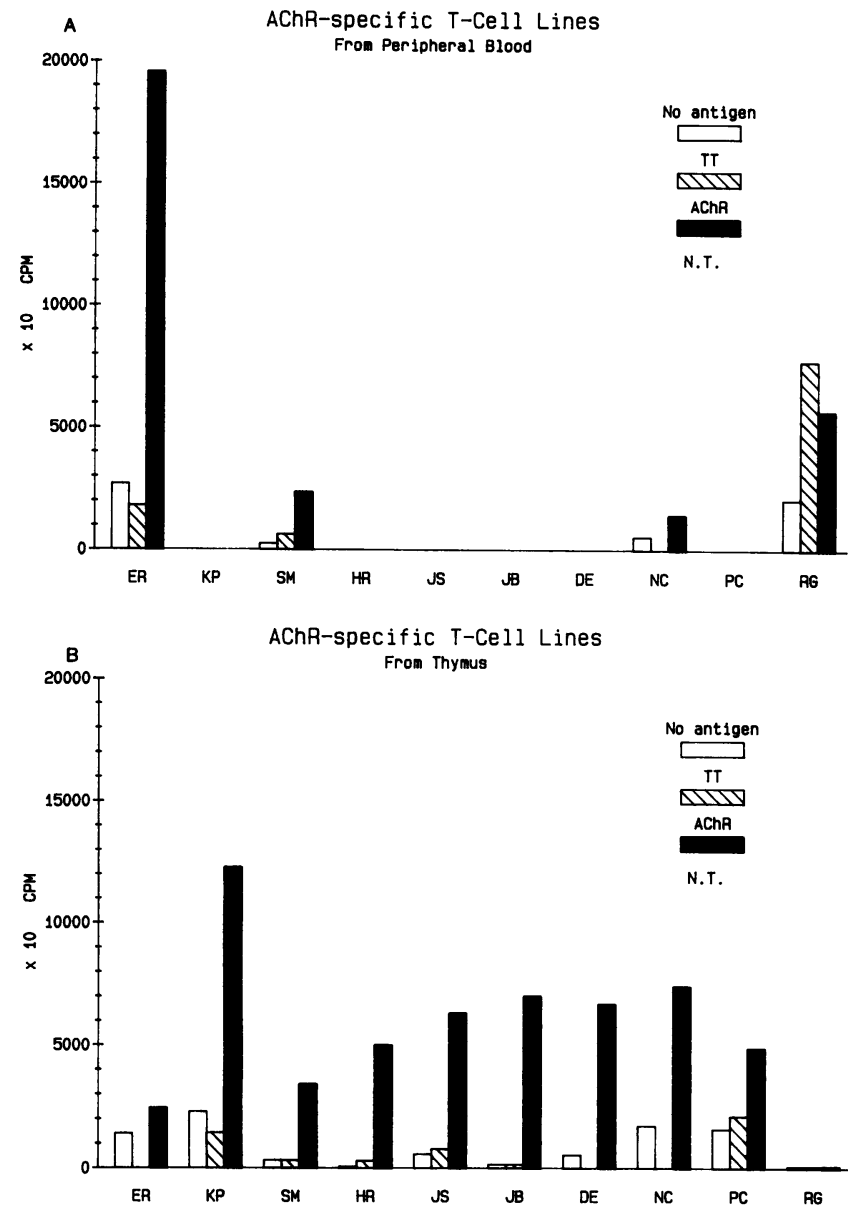

Figure 3. Antigen-induced $\mathrm{T}$ cell proliferation of $2 \times 10^{4} \mathrm{~T}$ line cells from peripheral blood $(a)$ and from thymus $(b)$ in the presence of irradiated, autologous antigen-presenting cells; $\left[{ }^{3} \mathrm{H}\right]$ thymidine incorporation, mean of triplicates $\pm \mathrm{SD}$. $\mathrm{NC}(A), \mathrm{ER}, \mathrm{DE}, \mathrm{NC}(B)$; not tested; KP, HR, JS, JB, DE, PC $(A)$; 0, attempted but failed.

myoid cells, which can also be induced in vitro to develop from primitive precursor cells $(24,25)$. As any antigen to be recognized by $\mathrm{T}$ cells, $\mathrm{AChR}$ has to be taken up, processed and reexpressed in the context of MHC antigens on the membranes by "professional" antigen presenting cells (26). The thymic medulla contains high numbers of such presenting cells, e.g., IDCs $(27,28)$. Three observations are in support of such a presentation mechanism. (a) Non-T, non-B thymic cells enhance anti-AChR Ig production by autologous PBL (29); (b) in some cases thymic cells could enhance proliferation of autologous PBL in myasthenic patients $(30,31) ;(c)$ as emphasized in our present studies, myasthenic thymus medulla contains ample amounts of $\mathrm{AChR}$ expressing, desmin-positive myoid cells (23), which are often in intimate contact with IDCs, and the latter are surrounded by mature $\mathrm{T} 3^{+} \mathrm{T}$ lymphocytes.

These findings provide support for an active role of the thymus in the immuno-pathogenesis of MG. In addition, they are compatible with, but do not prove the concept of an intrathmyic first phase of myasthenic pathogenesis. Still, our present data do not definitely establish the origin of AChR specific thymic $T$ cells. It should be noted that, in contrast to former views, the normal thymic medulla is by no means completely secluded from the peripheral immune cell traffic. This is certainly also the case for the thymus in MG. A hallmark of MG thymus tissue is the "peripheralization" of its medulla. Most MG thymuses contain significant numbers of germinal centers with B lymphocytes and enlarged regions of immunocompetent mature $T$ lymphocytes (32-36). Some of the B cells seem to be in an activated state (37) and can be shown to synthesize autoantibodies against $\mathrm{AChR}(38,39)$, and permanent AChR specific B cell lines have been derived from MG thymuses (40). One may assume quite confidently that most, if not all B cells specific for AChR or other antigens in myasthenic thymuses are the progeny of B lymphocytes immigrated from the peripheral immune system. Moreover, recent experimental evidence suggests, that even in normal rodent thymuses activated $\mathrm{T}$ lymphocytes will immigrate via the blood circulation. This has been shown by tracing immune $T$ cells to the thymus either after active immunization $(41,42)$ or after injection of activated $T$ line cells (43). The immune status of the thymus is further complicated by the observation that soluble antigen can enter the medulla and be immunogenically presented by local presenter cells (44). Indeed, in our series of myasthenic thymuses, besides $A C h R$ reactive $T$ cells we also demonstrated $\mathrm{T}$ lymphocytes reacting against $\mathrm{TT}$ as a control (foreign) antigen. It is thus open, whether TT specific T cells count among those $T$ lymphocytes that have immigrated to the thymus after encountering their antigen in the periphery. In principle, the $A C h R$ specific $T$ cells demonstrated in our study may well be secondary immigrants as well rather than the direct progeny of intrathymically differentiating precursor

Table II. Surface Membrane Phenotype of Fresh Separated Thymocytes and of a Thymus-derived $A C h R$-specific T cell Line (FACS = Analysis)

\begin{tabular}{|c|c|c|c|c|c|c|c|c|}
\hline \multirow[b]{2}{*}{ Cells } & \multicolumn{8}{|c|}{ Surface markers ( $\%$ positive) } \\
\hline & Control & T 3 & T 4 & T 6 & T 8 & HLA-DR & IL 2R & RAHIG \\
\hline \multicolumn{9}{|l|}{ Thymocytes } \\
\hline Nonseparated & 2 & ND & 55 & 78 & 47 & 2 & 1.2 & 0.2 \\
\hline High density & 2 & 36 & 51 & 78 & 60 & 0.2 & 0.8 & 0.2 \\
\hline Low density & 2 & 32 & 49 & 79 & 21 & 6.6 & 1.6 & 1.7 \\
\hline \multicolumn{9}{|l|}{ AChR specific } \\
\hline $\mathrm{T}$ cell line & 2.8 & 95 & 95 & 3 & 3 & 95 & 51 & ND \\
\hline
\end{tabular}

Control: FITC conjugated $\mathrm{F}(\mathrm{ab})_{2}$ fragment of goat anti-mouse IgG, without primary typing mABs. RAHIG, rabbit anti-human immunoglobulin-FITC conjugated. 
cells. It should, however, be noted that the tissue distribution of AChR and TT specific T cells differed quite markedly. TT specific $\mathrm{T}$ cells could be isolated from peripheral blood of immune donors almost unfailingly. Within MG thymuses they were also demonstrable, but seemed to be somewhat less frequent than among peripheral blood lymphocytes. In contrast, the establishment of $\mathrm{AChR}$ specific $\mathrm{T}$ lines from peripheral blood lymphocytes, in agreement with other workers (45), was difficult. AChR specific T lines were, however, regularly isolated from the thymus tissues from the same myasthenic patients of our series.

Taken together, these data provide circumstantial evidence for a relative enrichment of $\mathrm{AChR}$ specific $\mathrm{T}$ cells within the myasthenic thymus, which could reflect either local expansion of peripheral, immigrant $\mathrm{AChR}$ specific $\mathrm{T}$ cells, or primary reactions of AChR specific $T$ cells newly formed within the thymus.

Most of the thymuses in our series showed lympho-follicular hyperplasia and were derived from patients within the first two years of symptoms. An interesting exception was patient $\mathrm{DE}$, who suffered from myasthenia for 20 years, was intermittently treated with azathioprine, and was found to have a benign thymoma. As reported in other studies $(2,46)$, the neoplastic tissue portion was joined by residual thymus tissue with lympho-follicular hyperplasia and marked germinal center formation and preponderant mature $\mathrm{T}^{+}$lymphocytes. Almost all of the thymomatous thymocytes had the immature, "cortical" $\mathrm{T}^{+}$phenotype, as described in other thymomas (47). Judging from their mature $\mathrm{T}^{+}, \mathrm{T}^{-}$phenotype, the AChR specific $T$ cells should have been derived from the perithymomatous thymus residuum rather than from the tumor tissue. It will be of interest to determine, whether this is true for other cases of thymic neoplasia and myasthenia.

What is the functional role of thymic AChR specific $T$ cells? First, no doubt, the pathogenesis of MG is based on anti-AChR autoantibodies which interfere with functional postsynaptic AChR (48). Direct T cellular immune effector mechanisms have not been proven so far. Most, if not all pathogenic autoantibodies have $\gamma$-isotypes (49), thus their synthesis depends on interactions of T-helper with B cells. All our thymus-derived T lines expressed the CD 4, "T-helper" membrane phenotype. They thus were analogous to $T$ lines isolated from MG peripheral blood by ourselves and by others (45). Indeed, Hohlfeld et al. showed that antigen recognition by blood-derived AChR specific T lines was restricted by HLA class II determinants (50) and that these cells were able to enhance in vitro production of anti AChR immunoglobulins by autologous blood B lymphocytes (51). Although these observations do not prove that all AChR specific $\mathrm{T}$ cells are indeed involved in the production of pathogenic autoantibodies, it seems reasonable to assume that the AChR specific $T$ lines contain at least some $T$ helper cells indirectly involved in the pathogenesis of MG. Our finding that the thymus apparently contains impressive numbers of such cells is compatible with an active role of the thymus in MG pathogenesis. It remains to be established whether the thymus indeed is the primary site of the myasthenogenic anti-AChR T cell reaction, as postulated by us before, or whether it acts as an amplifier or a depot of pathogenic $\mathrm{T}$ helper cells. In either case, however, thymectomy at an early stage of disease would be justified as a radical and rational therapy.

\section{Acknowledgments}

We thank Mrs. B. Goebel for typing the manuscript, and Dr. A. Maelicke for advice in acetylcholine receptor preparation.

This Unit is supported by funds of the Hermann-and-Lilly-Schilling-Foundation. A. Melms is recipient of a postdoctoral fellowship from the Deutsche Forschungsgemeinschaft.

\section{References}

1. Castleman, B. 1966. The pathology of the thymus in myasthenia gravis. Ann. NY Acad. Sci. 135:496-503.

2. Penn, A. S., A. Jaretzki, M. Wolff, H. W. Chang, and V. Tennyson. 1981. Thymic abnormalities. Antigen or antibody? Response to thymectomy in myasthenia gravis. Ann. NY Acad. Sci. 377:786-803.

3. Olanow, C. W., A. S. Wechsler, and A. D. Roses. 1982. A prospective study of thymectomy and serum acetylcholine receptor antibodies in myasthenia gravis. Ann. Surg. 196:113-121.

4. Monden, Y., K. Nakahara, K. Kagotani, Y. Fujii, S. Nanjo, A. Masoka, and Y. Kawashima. 1984. Effects of preoperative duration of symptoms in patients with myasthenia gravis. Ann. Thorac. Surg. 38:287-291.

5. Hankins, J. R., R. F. Mayer, J. R. Satterfield, S. Z. Turney, S. Attar, A. J. Sequeira, B. W. Thompson, and J. S. McLaughlin. 1985. Thymectomy for myasthenia gravis: 14 years experience. Ann. Surg. 201:613-615.

6. Abramsky, O., A. Aharonov, C. Webb, and S. Fuchs, 1975. Cellular immune response to acetylcholine receptor rich fraction in patients with myasthenia gravis. Clin. Exp. Immunol. 19:11-16.

7. Conti-Tronconi, B. M., M. Morgutti, A. Sghirlanzoni, and F. Clementi. 1979. Cellular immune response against acetylcholine receptor in myasthenia gravis. I. Relevance to clinical course and pathogenesis. Neurology. 29:469-501.

8. Richman, D. P., J. P. Antel, J. W. Patrick, and B. G. W. Arnason. 1979. Cellular immunity of acetylcholine receptor in myasthenia gravis. Relationship to histocompatibility type and antigenic site. Neurology. 29:291-296.

9. Wekerle, H., B. Paterson, U.-P. Ketelsen, and M. Feldman. 1975. Striated muscle fibers differentiate in monolayer cultures of adult thymus reticulum. Nature (London.). 256:493-494.

10. Wekerle, H., and U.-P. Ketelsen. 1977. Intrathymic pathogenesis and dual genetic control of myasthenia gravis. Lancet. i:678-680.

11. Wekerle, H., R. Hohlfeld, U.-P. Ketelsen, J. R. Kalden, and I. Kalies. 1981. Thymic myogenesis, T lymphocytes and the pathogenesis of myasthenia gravis. Ann. NY Acad. Sci. 377:455-475.

12. Schalke, B. C. G., L. Kappos, D. Dommasch, E. Rohrbach, and H. G. Mertens. Cyclosporin (CyA) in the treatment of myasthenia gravis: First results of a double blind trial CyA versus azathioprine. Ann. NY Acad. Sci. In press.

13. Osserman, K. E. 1958. Myasthenia Gravis. Grune \& Stratton, Inc., New York.

14. Lindstrom, J. M., and J. Patrick. 1974. Purification of acetylcholine receptor by affinity chromatography. In Synapic transmission and neuronal interaction. M. V. L. Bennett, editor. Raven Press, New York. 191-216.

15. Rüchel, R., D. Watters, and A. Mälicke. 1981. Molecular forms and hydrodynamic properties of acetylcholine receptor from electric tissues. Eur. J. Biochem. 119:215-223.

16. Schmidt, V., and M. A. Raftery. 1973. A. simple assay for the study of solubilized acetylcholine receptors. Anal. Biochem. 52:349354.

17. Albert, E., M. P. Baur, and W. R. Mayr, editors. 1985. Histocompatibility testing 1984. Springer-Verlag, Heidelberg, F.R.G.

18. Radzun, H.-J., M. R. Parwaresch, A. C. Feller, and M. L. 
Hansmann. 1983. Monocyte/macrophage-specific monoclonal antibody Ki M 1 recognizes interdigitating reticulum cells. Am. J. Pathol. 117:441-450.

19. Parwaresch, M. R., H.-J. Radzun, M. L. Hansmann, and K. P. Peters. 1983. Monoclonal antibody Ki M 4 specifically recognizes human dendritic reticulum cells (follicular dendritic cells) and their possible precursors in blood. Blood. 62:585-590.

20. Stein, H., J. Gerdes, U. Schwab, H. Lemke, D. Y. Mason, A. Ziegler, W. Schienly, and V. Diehl. 1982. Identification of Hodgkin and Sternberg-Reed cells as a unique cell type derived from a newly detected small-cell population. Int. J. Cancer. 30:445-459.

21. Feller, A. C., M. R. Parwaresch, H.-H. Wacker, H.-J. Radzun, and K. Lennert. 1983. Combined immunohistochemical staining for surface IgG and $\mathrm{T}$ lymphocyte subsets with monoclonal antibodies in human tonsils. Histochem. J. 15:557-562.

22. Compston, D. A. S., A. Vincent, J. Newsom-Davis, and J. R. Batchelor. 1980. Clinical, pathological, HLA antigen and immunological evidence for disease heterogeneity in myasthenia gravis. Brain. 103:579-801.

23. Kirchner, Th., S. Tzartos, F. Hoppe, B. Schalke, H. Wekerle, and H. K. Müller-Hermelink. 1988. Pathogenesis of myasthenia gravis: Acetylcholine receptor-related antigenic determinants in tumor-free thymuses and thymic epithelial tumors. Am. J. Pathol. In press.

24. Kao, I., and D. B. Drachman. 1977. Thymic muscle cells bear acetylcholine receptors. Possible relation to myasthenia gravis. Science (Wash. DC.). 195:74-75.

25. Wekerle, H., U.-P. Ketelsen, A. Zürn, and B. W. Fulpius. 1978. Intrathymic pathogenesis of myasthenia gravis: Transient expression of acetylcholine receptors and thymus derived muscle cells. Eur. J. Immunol. 8:579-583.

26. Unanue, E. R., D. I. Beller, C. Y. Lu, and P. M. Allen. 1984. Antigen presentation: Comments on its regulation and mechanism. $J$. Immunol. 132:1-5.

27. Kaiserling, R., H. Stein, and H. K. Müller-Hermelink. 1974. Interdigitating cells in the human thymus. Cell Tissue Res. 155:47-55.

28. Vanvoorhis, W. C., J. Valinski, E. Hoffman, J. Luban, J. S. Hair, and R. M. Steinman. 1983. The relative efficacity of human monocytes and dendritic cells as accessory cells for T replication. $J$. Exp. Med. 158:174-191.

29. Newsom-Davis, J., N. Willcox, and L. Calder. 1981. Thymus cells in myasthenia gravis selectively enhance production of anti-acetylcholine receptor blood lymphocytes. N. Engl. J. Med. 305:13131318.

30. Abdou, A. L., R. P. Lisak, E. Zweiman, I. Abrahamson, and A. S. Penn. 1974. The thymus in myasthenia gravis. Evidence for altered cell populations. $N$. Engl. J. Med. 291:1271-1275.

31. Opelz, G., J. Keesey, M. M. Glovsky, and R. P. Gale. 1978. Autoreactivity between lymphocytes and thymus cells in myasthenia gravis. Arch. Neurol. 35:413-415.

32. Alpert, L. I., A. Papatestas, A. Kark, R. S. Osserman, and K. E. Osserman. 1971. Histologic reappraisal of the thymus in myasthenia gravis. Arch. Pathol. 91:55-61.

33. Kirchner, Th., B. C. G. Schalke, A. Melms, Th. von Kügelgen, and H. K. Müller-Hermelink. 1986. Immunohistological pattern of non-neoplastic changes in the thymus of myasthenia gravis. Virchows Arch. (Cell. Pathol.) 52:237-257.

34. Wiersbowsky-Schmeel, A., B. Helpap, V. Totvic, and V. Grouls. 1984. Thymus in myasthenia gravis: A light and electron microscopic study of a case with thymic follicular hyperplasia. Pathol. Res. Pract. 178:323-331.
35. Bofill, M., G. Janossy, N. Willcox, M. Chilosi, J. K. Trejdosievic, and J. Newsom-Davis. 1985. Microenvironment in the normal thymus and the thymus in myasthenia gravis. Am. J. Pathol. 119:462473.

36. Wekerle, H., and H. K. Müller-Hermelink. 1986. The thymus in myasthenia gravis. Curr. Topics Pathol. 75179-206.

37. Levinson, A. I., B. Zweiman, R. P. Lisak, A. Dziarski, and A. R. Moskovitz. 1984. Thymic B cell activation in myasthenia gravis. Neurology. 34:452-468.

38. Vincent, A., G. Scadding, H. C. Thomas, and J. NewsomDavis. 1978. In vitro synthesis of anti-acetylcholine-receptor antibody by thymic lymphocytes in myasthenia gravis. Lancet. i:305-307.

39. Fujii, Y., Y. Monden, J. Hashimoto, K. Nakahara, and Y. Kawashima. 1985. Acetylcholine-receptor antibody-producing cells in thymus and lymph nodes in myasthenia gravis. Clin. Immun. Immunopathol. 34:141-146.

40. Kamo, I., S. Furukawa, A. Tada, Y. Mano, Y. Iwasaki, T. Furuse, N. Ito, K. Hayashi, and E. Satoyoshi. 1982. Monoclonal antibody to acetylcholine-receptor: Cell line established from thymus of patient with myasthenia gravis. Science (Wash. DC). 215:995-996.

41. Ben-Nun, A., and I. R. Cohen. 1982. Spontaneous remission and acquired resistance to autoimmune encephalomyelitis (EAE) are associated with suppression of T cell reactivity: Suppressed EAE effector cells recovered as T cell lines. J. Immunol. 128:1450-1457.

42. Fink, P. J., M. J. Bevan, and I. L. Weissman. 1984. Thymic cytotoxic $\mathrm{T}$ cells are primed in vivo to minor histocompatibility antigen. J. Exp. Med. 159:436-451.

43. Naparstek, Y., J. Holoshitz, S. Eisenstein, R. Reshef, S. Rappaport, J. Chemkes, A. Ben-Nun, and I. R. Cohen. 1982. Effector T lymphocyte line cells migrate to the thymus and persist there. Nature (Lond.). 300:262-264.

44. Kyewski, B. A., C. G. Fathman, and H. S. Kaplan. 1984. Intrathymic presentation of circulating non-MHC antigens. Nature (Lond.). 308:196-199.

45. Hohlfeld, R., K. V. Toyka, K. Heininger, H. Grosse-Wilde, and I. Kalies. 1984. Autoimmune human T lymphocytes specific for acetylcholine receptor. Nature (Lond.). 310:244-246.

46. Monden, Y., K. Nakahara, K. Kagotani, Y. Fujii, A. Masaoka, and Y. Kawashima. 1984. Myasthenia gravis with thymoma: Analysis of and postoperative prognosis for 65 patients with thymomatous myasthenia gravis. Ann. Thorac. Surg. 38:46-52.

47. Aisenberg, A. C., B. Wilkes, N. L. Harris, and W. H. Frist. 1985. The predominant lymphocyte in most thymomas and in non-neoplastic thymus from patients with myasthenia gravis is the cortical thymocyte. Clin. Immun. Immunopathol. 35:130-136.

48. Drachman, D. B., R. N. Adams, L. F. Josifek, and S. G. Self. 1982. Functional activities of autoantibodies to acetylcholine receptors and the clinical severity of myasthenia gravis. N. Engl. J. Med. 307:769-775.

49. Toyka, K. V., D. B. Drachman, D. E. Griffin, A. Pestronk, J. A. Winkelstein, K. H. Fischbeck, and I. Kao. 1977. Myasthenia gravis: Study of humoral immune mechanisms by passive transfer to mice. $N$. Engl. J. Med. 296:125-131.

50. Hohlfeld, R., B. Conti-Tronconi, I. Kalies, J. Bertrams, and K. V. Toyka. 1985. Genetic restriction of autoreactive acetylcholine receptor specific $\mathrm{T}$ lymphocytes in myasthenia gravis. J. Immunol. 153:2393-2399.

51. Hohlfeld, R., I. Kalies, B. Kohleisen, K. Heininger, B. M. Conti-Tronconi, and K. V. Toyka. 1986. Myasthenia gravis: Stimulation of antireceptor autoantibodies by autoreactive $\mathrm{T}$ cell lines. Neurology. 36:618-621. 